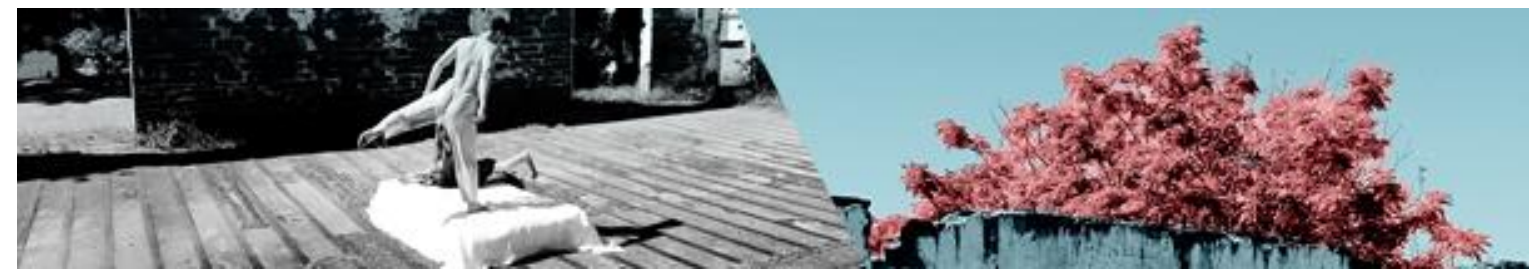

\title{
CORPO ESTRANHO: O DESAMPARADO QUE ENCONTRA SUA POLÍTICA DE SER
}

\author{
Juliano Ribeiro Farial \\ Marcos Antônio Bessa-Oliveira ${ }^{2}$
}

\begin{abstract}
Resumo: Este trabalho emerge como pesquisa em Arte a partir da condição na qual sempre fui colocado, de corpo estranho, por ser imperfeito ao modelo de corpo colonizado imposto no mundo. Continuamente, por isso, vivo sendo posto na categoria de "Ser menos", como outros tantos corpos estranhos também vivem: ocupando o lugar do fundo na cena para deixar a coreografia em dança uniforme ou as apresentações teatrais ou musicais mais belas na escola. Deste modo, construo esta pesquisa ancorado em uma episteme cultural, que é também uma luta escrita/inscrita no meu próprio corpo, para dar visibilidade ao corpo estranho como produtor de arte, cultura e conhecimentos, quando esse encontra sua casa, o "seu corpo" (BERTHERAT, 2010) na escola.
\end{abstract}

Palavra-chave: Corpo estranho; Escola; Visibilidade.

\section{STRANGE BODY: THE HELPLESS THAT FINDS ITS POLITICS OF BEING}

\begin{abstract}
This work emerges as a research in Art from the condition in which I have always been placed, of foreign body, being imperfect to the model of colonized body imposed in the world. Continuously, therefore, I live being put in the category of "Being less", as so many foreign bodies also live: taking the place of the background in the scene to leave the choreography in uniform dance or the most beautiful theatrical or musical performances in school. In this way, I build this research anchored in a cultural episteme, which is also a written/written struggle in my own body, to give visibility to the foreign body as a producer of art, culture and knowledge, when he finds his home, his "body" (BERTHERAT, 2010), in school.
\end{abstract}

Keyword: Strange body; School; Visibility.

\section{Introdução - O que abriga a minha biogeografia}

\begin{abstract}
"Eu costumava achar que eu era a pessoa mais estranha do mundo, mas aí eu pensei: tem que ter alguém como eu, que se sinta bizarra e imperfeita, da mesma maneira como eu me sinto. E eu imaginava esta pessoa, imaginava que ela também estivesse lá pensando em mim. Bom, espero que se você for essa pessoa e estiver lendo isto, saiba que sim é verdade, estou aqui! Sou estranha como você." (Frida Kahlo).
\end{abstract}

\footnotetext{
${ }^{1}$ Juliano Ribeiro Faria - Possui graduação em Artes Cênicas e Dança pela Universidade Estadual de Mato Grosso do Sul (2018). Tem experiência na área de Artes, com ênfase em artes cênicas.

${ }^{2}$ Marcos Antônio Bessa-Oliveira - Graduado em Artes Visuais e Mestre em Estudos de Linguagens pela UFMS - Universidade Federal de Mato Grosso do Sul, Doutor em Artes Visuais pelo IAR UNICAMP. É professor do curso de Graduação em Artes Cênicas (TEATRO e DANÇA) da e do PROFEDUCA - Programa de Mestrado Profissional em Educação - UEMS - Universidade Estadual de Mato Grosso do Sul - na Cadeira de Artes Visuais ministrando as disciplinas de História da Arte, Artes Visuais, Itinerários Científicos III, Arte e Cultura Regional, Arte Educação, Itinerários Científicos IV para os 1ํㅜㄴ $3^{\circ}$ e $4^{\circ}$ anos do curso. É líder do Grupo de Pesquisa NAV(r)E - Núcleo de Artes Visuais em (re)Verificações Epistemológicas - UEMS/UEMS. É membro do NECC - Núcleo de Estudos Culturais Comparados - UFMS e do Núcleo de Estudos Visuais - UNICAMP.
}

FARIA, Juliano Ribeiro; BESSA-OLIVEIRA, Marcos Antônio. Corpo estranho: o desamparado que encontra sua política de ser. Revista da FUNDARTE, Montenegro, p.396-415, ano 19, no 37 , Janeiro/Março.

Disponível em: http://.seer.fundarte.rs.gov.br/index.php/RevistadaFundarte/index> 30 de março de 2019. 


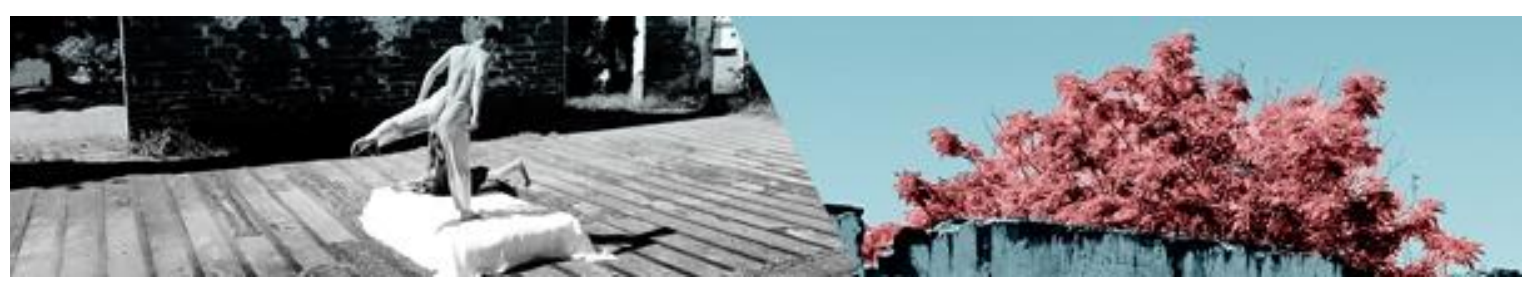

Esta pesquisa emerge primeiro a partir da condição na qual sempre fui colocado: um corpo de Ser menos; e me orgulho deste lugar, que nunca me possibilitou "ser mais do mesmo" para ser alguém. Esta colocação me fez, desde cedo, lutar com meu corpo estranho pelo meu lugar de Ser, ainda que o mundo e o espaço nos quais me encontrava - ou me encontro nos dias atuais - contribuam para o contrário. Meu corpo é situado em um lugar, mantendo-se fechado às minhas estranhezas, o que me gerou marcas sofridas, as quais aprendi a carregar, e que me transformaram; e, aliás, me fizeram amar o meu jeito de ser: estranho, imperfeito, bizarro e talvez um jeito político anormal de Ser, que a maioria das pessoas não admirariam ser.

Este trabalho fez emergir outras reflexões, que hoje se dão como uma pesquisa sobre o ensino de Arte atual, como segunda questão fundamental a ser debatida: os múltiplos corpos estranhos encontrados na disciplina de Arte nas duas escolas de Campo Grande-MS onde realizei o estágio supervisionado obrigatório pré-requisito para conclusão do Curso de Artes Cênicas-Licenciatura da UEMS nos anos de 2017 e 2018. Deste modo, a construção desta pesquisa é feita a partir de uma luta inscrita no meu próprio corpo, mas como escrita para dar visibilidade e discutir os vários corpos estranhos presentes nas aulas de Arte, que devem ser vistos também como produtores de arte, cultura e conhecimentos quando esses corpos todos encontram suas moradas: "seu corpo" (BERTHERAT, 2010) na escola. Ao abordar esses corpos estranhos como produtores e não (re)produtores de arte, cultura e conhecimentos, proponho uma argumentação epistêmica contramoderna.

Desta forma, a ordem de como ser corpo no mundo está marcada nos corpos que transitam nos espaços da sociedade e da escola, modelos de corpos que carregam a consciência da perfeição em suas memórias, a "marca" (DERRIDA) de corpo moderno que (re)produz arte, cultura, conhecimento alheios. Um padrão no qual o corpo estranho que habito e penso para fora de mim, nesta escrita e de outros trabalhos já realizados sobre o corpo estranho, deixa e vem deixando rastros do meu aparelho psíquico posto/imposto "sob rasura" (DERRIDA,1973, p. 60), no presente e no passado, do contato com o corpo perfeito nos espaços. Perceb(i)o a

FARIA, Juliano Ribeiro; BESSA-OLIVEIRA, Marcos Antônio. Corpo estranho: o desamparado que encontra sua política de ser. Revista da FUNDARTE, Montenegro, p.396-415, ano 19, № 37, Janeiro/Março.

Disponível em: http://.seer.fundarte.rs.gov.br/index.php/RevistadaFundarte/index> 30 de março de 2019. 


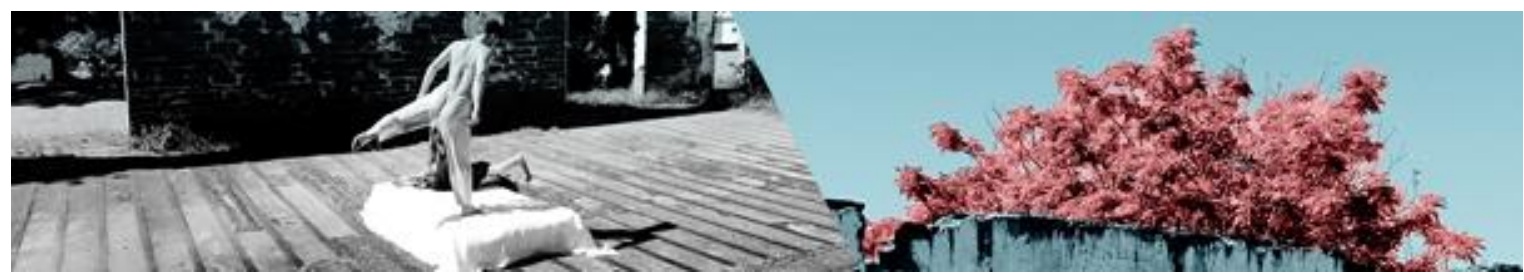

rejeição do meu corpo na expressão dele(a) e senti/sinto as tentativas de substituição do meu corpo pelo corpo correto, por meio de incisões, gerando em mim cicatrizes que (re)vivem na minha memória de ser menos esta marca de corpos colonizados. Isso, Jacques Derrida endossa ao afirmar que "não há arquivo sem lugar de consignação, sem uma técnica de repetição e sem uma certa exterioridade. Não há arquivo sem exterior" (DERRIDA, 2001, p. 22). Não há memória/arquivo sem lugar/corpo de consignação! Não há nenhum corpo sem memória/arquivo!

Foi na história, na cultura, na religião, na ciência da "marca" (DERRIDA) hegemônica desses que nas(cres)ceu o meu corpo estranho, um corpo sempre kahlado pelas minhas imperfeições, por não ser original ao corpo perfeito cristalizado no mundo. Por isso incessantemente sou colocado na condição de ser menos como outros corpos estranhos também o são; corpos sendo vistos como algo equivocado. Assim, como consequência desse equívoco, constituo esta pesquisa que para mim é uma luta que sempre esteve implícita/inscrita em meu próprio corpo: "um corpo racialmente marcado em um espaço geo-historicamente marcado, [que] sente a urgência ou a necessidade de falar, de articular [...]" (MIGNOLO, 2009, p. 10. [Tradução livre minha])

A partir do espaço que me encontro hoje, na Universidade Estadual de Mato Grosso do Sul, faço do meu corpo imperfeito para muitos um corpo-política no curso de Artes Cênicas, o lugar do "ser mais", e do meu direito também. Pois sou consciente de um conhecimento localizado em meu corpo que está fora do padrão moderno, assim como em outros corpos estranhos em que todo "conhecimento é construído" (MIGNOLO, 2009) através da nossa imperfeição. Compreendo que não somos como "corpos dóceis" de Michel Foucault (1987), corpos submissos à (re)produção dos mesmos conhecimentos e da manutenção do discurso de ser e ensinar a ser corpo. Por isso, venho dar visibilidade ao corpo estranho apresentando-o como produtor de arte, cultura e conhecimento outros, (re)significando a visão estereotipada de corpo perfeito sobre os corpos que são estranhos.

FARIA, Juliano Ribeiro; BESSA-OLIVEIRA, Marcos Antônio. Corpo estranho: o desamparado que encontra sua política de ser. Revista da FUNDARTE, Montenegro, p.396-415, ano 19, № 37, Janeiro/Março.

Disponível em: http://.seer.fundarte.rs.gov.br/index.php/RevistadaFundarte/index> 30 de março de 2019. 


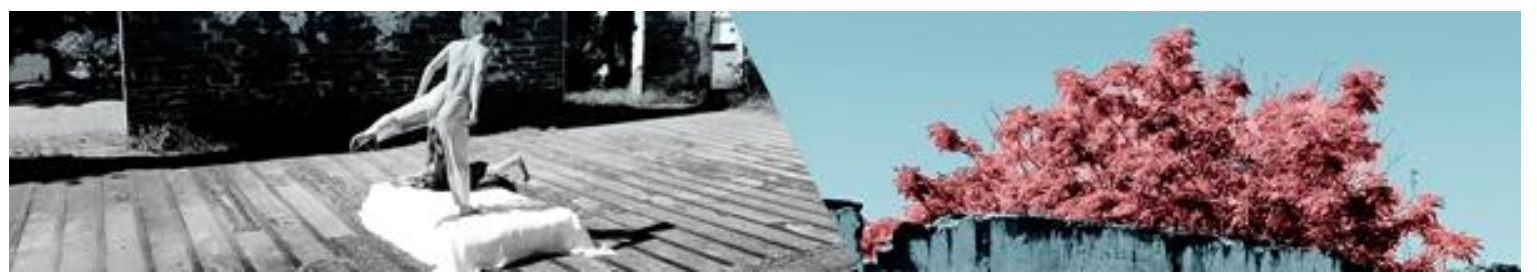

Pedagogia da perfeição e pedagogia da imperfeição em prática na escola

A pedagogia da perfeição é uma prática comum nas escolas, no ensino de arte, mas que é já falida, pois busca ensinar aos estudantes a (re)produzir "cópia=modelo" (BESSA-OLIVEIRA, 2010, p. 73), a exemplo de artistas da História da Arte europeia. O educador é quem conduz o conteúdo ao estudante, que é visto como uma "vasilha" (FREIRE, 1987, p. 58), um recipiente oco que deve ser "enchido" (FREIRE, 1987, p. 58), preenchido ou modelado com um conhecimento específico. Segundo Paulo Freire, ao educador não cabe outro papel se não o:

[...] de disciplinar a entrada do mundo nos educandos. Seu trabalho será, também, o de imitar o mundo nos educandos. O de ordenar o que já se faz espontaneamente. O de "encher" os educandos de conteúdos. É o de fazer depósitos de "comunicados" - falso saber - que ele considera como verdadeiro saber. (FREIRE, 1987, p. 63).

Com esta prática de ensino "bancária" (FREIRE, 1987, p. 62) o estudante aprende que o único corpo que produz arte, cultura e conhecimento é o corpo branco heterossexual europeu, o corpo perfeito, e que para atuar em arte, este corpo deve saber desenhar apenas formas belas, calculadas; só assim a sua produção artística será vista e bem avaliada. Para falar em arte da cena, apenas será corpo aquele que melhor mover-se nos melhores espaços. O estudante é educado para ter uma "consciência colonizada" (FREIRE, 1987, p. 50), que o faz pensar que vive em um corpo perfeito, mesmo sendo de classe pobre e estudando em escola pública e, por isso, sendo um corpo estranho. Um corpo que carrega uma consciência colonizadora da perfeição como espaço/arquivo de um modelo de corpo no seu corpo estranho.

Por viverem imersos nesta pedagogia que não dialoga com os múltiplos corpos, que estão em um mundo diferente do seu modelo de corpo perfeito que realiza "cópia=modelo" (BESSA-OLIVEIRA, 2010, p. 73) de desenhos belos, os corpos da diferença, da exterioridade ao modelo europeu, são desconsiderados pelos professores e colegas. A exemplo do corpo estranho que penso e habito, que é também um "corponeg(r)ado" (BESSA-OLIVEIRA, 2018, p. 2) na prática da

FARIA, Juliano Ribeiro; BESSA-OLIVEIRA, Marcos Antônio. Corpo estranho: o desamparado que encontra sua política de ser. Revista da FUNDARTE, Montenegro, p.396-415, ano 19, № 37, Janeiro/Março.

Disponível em: http://.seer.fundarte.rs.gov.br/index.php/RevistadaFundarte/index> 30 de março de 2019. 


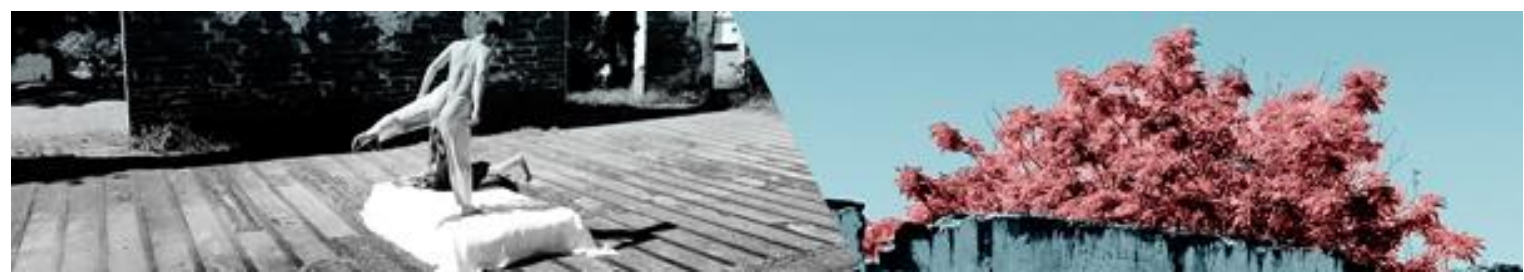

perfeição, por produzir traços imperfeitos, não faço arte, não pertenço a uma cultura e não produzo conhecimentos, pois corpos estranhos fogem da estética do belo, do padrão cultural europeu e da consciência única de que conhecimento é ciência. Portanto, assim como outros corpos estranhos também não o são corpos perfeitos, somos silenciados, desconsiderados e apagados por ela (a ciência moderna), pelos que acreditam naquela pedagogia disciplinar que personifica o corpo perfeito. Muitos corpos estranhos, como eu, crescem nesta pedagogia que (de)forma, sofrem com correções, rejeições e padrões de arte impostos.

Apresento a seguir uma citação de outra discussão nossa para complementar a ideia de que os corpos estranhos não têm nem voz e nem vez quando abordados por saberes e práticas docentes disciplinares (perfeitas):

\begin{abstract}
Os corpos que são estranhos sempre ocupam o lugar do fundo para deixar a coreografia uniforme ou as apresentações teatrais e musicais mais belas, mas sempre os espectadores percebem os movimentos estranhos escondidos no fundo que se sobressaem em relação aos outros corpos uniformemente sincronizados. Os corpos estranhos acabam sendo considerados mal-educados, burros, chatos, relaxados, entre outras palavras que fazem demonstração de exclusão do diferente nas semelhanças que os corpos modernos devem apresentar. (FARIA; BESSAOLIVEIRA, 2017, p. 5)
\end{abstract}

Após viver anos da minha vida dentro dessa pedagogia opressora, que nunca me ensinou a confiar no meu corpo como ele é, e sim a olhar com desprezo meu próprio corpo, fui adestrado para tentar ser como o corpo do outro. Para poder viver, para vir a ser e sentir, ocorria comigo constantemente "adestramento[s] forçado[s] do [meu] corpo carne, [...] considerado sem inteligência, como um ser animal a domar. (BERTHERAT, 2010, p. 3). Um propósito para ser humanizado dentro do padrão, "como se a única possibilidade de sobreviver fosse aderir a lógica [dessa] imunização" (GREINER, 2017, p. 18), contra minha imperfeição. A rigidez inconscientemente foi habitando o meu corpo, reprimindo a minha desobediência, matando o que seria um saber outro em relação ao mundo que define o saber sobre corpo. Pois a "Escola da contemporaneidade ainda está assentada no pensamento moderno de gênero, raça e classe, e se vale de ensino tecnicista para (re)formar"

FARIA, Juliano Ribeiro; BESSA-OLIVEIRA, Marcos Antônio. Corpo estranho: o desamparado que encontra sua política de ser. Revista da FUNDARTE, Montenegro, p.396-415, ano 19, ํo 37, Janeiro/Março.

Disponível em: http://.seer.fundarte.rs.gov.br/index.php/RevistadaFundarte/index> 30 de março de 2019. 


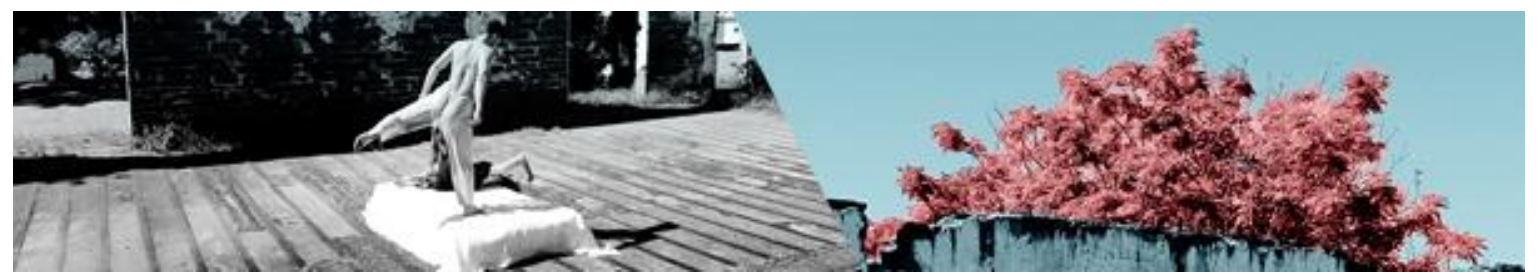

(FARIA; BESSA-OLIVEIRA, 2017, p. 2) corpos que estão sob sua responsabilidade, em seu âmbito escolar disciplinar, castrador.

Em casa nunca foi diferente! O amor à morte do meu corpo, por um corpo perfeito, sempre se fazia presente. Com isso, continuamente tive construídas cicatrizes no meu corpo que me marcaram (DERRIDA) e com o tempo

[...] não participava mais da vida. [Me sentia] um ser à parte, humilhad[o], castigad[o], sozinh[o] com a dor. Como um animal preso numa armadilha, o único jeito que [eu] via para fugir [da] dor era amputar a parte que doía, abandoná-la. (BERTHERAT, 2010, p. 25).

Amputei a parte da minha dor de/no corpo saindo de casa. Essa foi a saída que vi para a possibilidade de fazer meu corpo estranho deixar de "ser menos" para passar a Ser mais, ainda que com todos os problemas que viam nele. Fui, e ainda estou, em busca de um lugar ao sol para corpos estranhos como o meu.

Saí de casa para cursar Artes Cênicas - Teatro e Dança - na Universidade Estadual do Mato Grosso do Sul, uma oportunidade para despertar o meu corpo quase morto para a vida. Neste curso me formei. Nele encontrei uma outra casa na disciplina de Percepção Corporal, com o meu nome/corpo estampado, lugar natural que sempre vivi de fora, vendo suas/minhas possibilidades já fechadas. Nunca tinha conseguido morar nele, no meu corpo. Aqui descobri Thérèse Bertherat no seu livro O Corpo tem suas razões (2010) onde a autora expõe o que é o meu corpo. O meu corpo abriga as minhas "biogeografias: bio - corpo estranho; geo - espaço da opressão, da inexistência; grafias - narrativas de rejeição e superação (FARIA; BESSA-OLIVEIRA, 2018, p. 1) que constróem o meu corpo estranho e que, por conseguinte, sou eu.

Sou o corpo estranho que abriga a casa da exterioridade que burla as "fronteiras/barras" impostas pelos discursos da "interioridade colonial moderna e [da] colonialidade do poder contemporâneo com fazeres [modelos] de arte, cultura e conhecimentos" (BESSA-OLIVEIRA , 2018, p. 2). Sou o corpo estranho que é um corpo falando da sua condição de exterioridade aos pensamentos moderno e pósmoderno; uma exterioridade hoje grafada, muitas vezes, pela crítica da técnica

FARIA, Juliano Ribeiro; BESSA-OLIVEIRA, Marcos Antônio. Corpo estranho: o desamparado que encontra sua política de ser. Revista da FUNDARTE, Montenegro, p.396-415, ano 19, № 37, Janeiro/Março.

Disponível em: http://.seer.fundarte.rs.gov.br/index.php/RevistadaFundarte/index> 30 de março de 2019. 


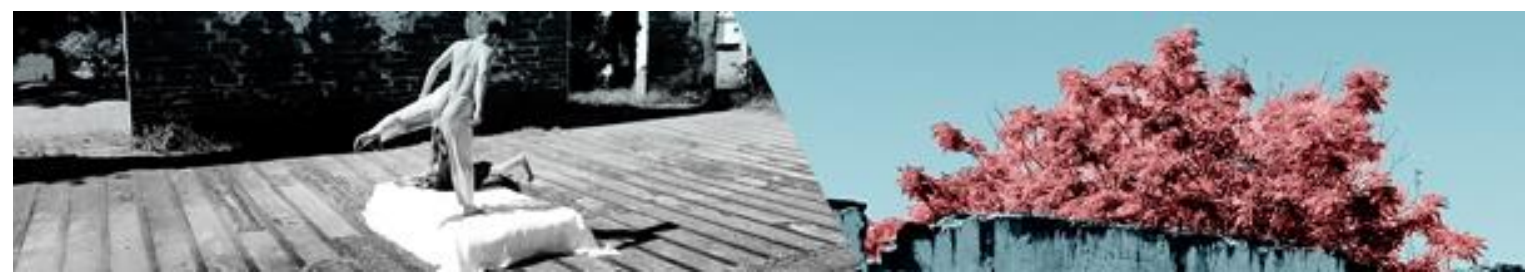

estabelecida em arte, de fronteira, de margem, de excluído de extracentros. Mas, mesmo assim, o corpo que habito é o corpo da exterioridade - é o corpo estranho que gera arte, cultura e conhecimentos a partir de si.

Nas Universidades não se promovem outras relações se não as continuações históricas estabelecidas de corpo, arte, cultura e conhecimentos (BESSA-OLIVEIRA, 2017, p. 11). A Universidade deveria ser o lugar onde os corpos (universais) estranhos pudessem REEXISTIR! E insistir nesse espaço como é posto ainda hoje, na maioria das vezes, mesmo em muitas delas pelos discursos políticos externos, que não se altera em relação aos outros lugares onde tinha vivido com meu corpo como é, pode reforçar a exclusão dos corpos estranhos alheios. Hissa (2011) aborda que os sujeitos que estão na universidade são profissionais que tomaram o espaço na universidade moderna, "no lugar dos intelectuais ativos, críticos. Se os sujeitos do conhecimento não se transformam, não desejam isso para si, não poderão, jamais, sequer imaginar o que seja a transformação do mundo noutros termos" (HISSA, 2011, p. 43). Muitas vezes me deparei com o CORPO PERFEITO neste espaço universitário, mas eu já tinha consciência da minha casa (corpo) e ele sabia que não podia mais adentrar aquele espaço da modernidade/perfeição.

Mas também foi na Universidade que encontrei coisas positivas como a teoria pós-colonial, por exemplo, como Bessa-Oliveira (2018) explica que esta oferece oportunidade aos corpos excluídos, aos corpos da exterioridade. Foi por meio dessa reflexão epistemológica que comecei a construir a pesquisa que resulta agora nesta reflexão, tendo como exemplo o corpo sofrido de Frida Kahlo para elucidar a concepção de corpo estranho imperfeito. Por conseguinte apresento uma citação onde trato um pouco sobre a relação que fiz de Frida com o (meu) corpo estranho que necessitava (re)existir:

Frida Kahlo ilustra a ideia de corpo estranho que pensamos, um corpo que se situa na contramão do corpo disciplinado. Aos 6 anos de idade aquele corpo já sofreu com poliomielite e em sua perna direita a doença deixara marcas; esta fez com que sua perna ficasse fina e o seu pé atrofiado. Em decorrência da doença Frida Kahlo ganhou o apelido de perna de pau dos seus colegas de escola, depois disso, mágoa e raiva passaram a habitar o coração ainda pequeno de Frida. Entretanto, como relata sua biografia, aquela criança ainda teve uma meninice feliz ao lado do pai, onde

FARIA, Juliano Ribeiro; BESSA-OLIVEIRA, Marcos Antônio. Corpo estranho: o desamparado que encontra sua política de ser. Revista da FUNDARTE, Montenegro, p.396-415, ano 19, ํo 37, Janeiro/Março.

Disponível em: http://.seer.fundarte.rs.gov.br/index.php/RevistadaFundarte/index> 30 de março de 2019. 


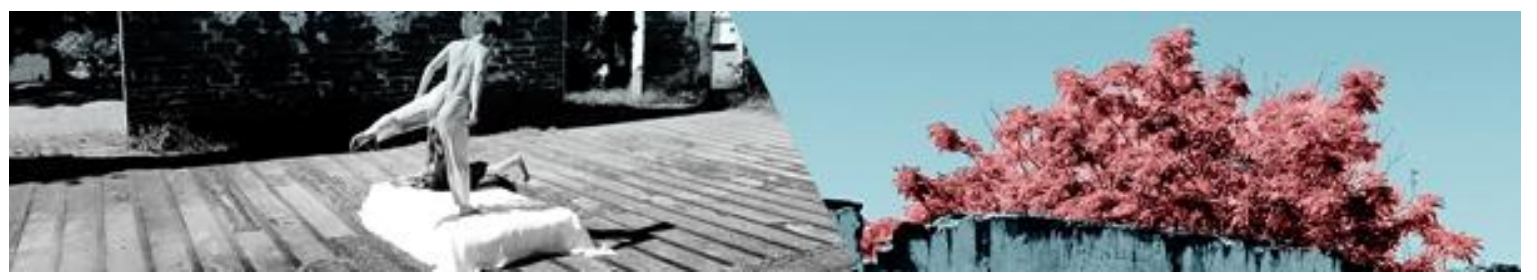

desenvolveu seu jeito masculino por conviver grande parte da infância com ele, já que sua mãe sofria de depressão. O que mais a vida poderia reservar a esse corpo que já tinha deformações e já sofria com preconceitos pelo seu jeito de ser, pois ela não detinha o corpo "normal", quase perfeito, que a sociedade impõe a nós até hoje? (FARIA; BESSA-OLIVEIRA, 2017, p. 10).

O corpo estranho "é um corpo desamparado que nada tem a perder. Ele é justamente aquele [que] pode agir politicamente" (GREINER, 2017, p. 19). E assim fui construindo este estudo sobre o corpo estranho, percebendo a pulsão do espectro de Frida e nos corpos estranhos que se encontram no "chão" da escola; corpos desamparados que mesmo assim sobrevivem às rejeições do outro que não os permitem ser gente, por serem imperfeitos, por ser dado ao estranho, ao diferente. Ao longo da pesquisa fui descobrindo que o corpo estranho com sua imperfeição é um corpo "que alimenta o pensamento descolonial ao imaginar um mundo no qual muitos podem coexistir" (MIGNOLO, 2008, p. 296); um corpo que habita o espaço da escola, mas um corpo que não existe na escola. Então, como fazer este corpo (re)existir? Ou melhor, como estes múltiplos corpos estranhos podem coexistir como apontou Mignolo? Ou ainda, como o corpo estranho pode ter direito e acesso à possibilidade de poder Ser mais (diferente)?

\section{De estranho e artista todo mundo tem um pouco!}

O corpo estranho me fez pensar para alcançar uma outra lógica metodológica de ensino de Arte, a pedagogia da imperfeição, uma prática que se forja com o estudante: "com ele" e "não para ele" (FREIRE, 1987, p. 32), para o empoderamento como anthropos $^{3}$ (corpo). Durante esta prática o educador e o educando podem fazer descobertas críticas sobre o mundo em que vivem. Podem promover "trabalhos educativos" (FREIRE, 1987, p. 41), organizados pelos educandos com apoio do educador. São pedagogias dentro da pedagogia da imperfeição "de trajetórias inventadas, [de] estratégias solidárias de criação" (HISSA, 2011, p. 14), que criam e se recriam possibilidades pedagógicas.

\footnotetext{
3 "Atualmente existem duas classes ou direções propostas pela antiga anthropos que não pede mais reconhecimento, ou inclusão na humanitas, mas sim se envolve em uma desobediência epistêmica e se desprende da ideia mágica da modernidade ocidental, dos ideais humanos e das promessas de crescimento econômico e prosperidade financeira (Wall Street dixit)." (MIGNOLO, 2009, p. 11) (Tradução livre minha)
}

FARIA, Juliano Ribeiro; BESSA-OLIVEIRA, Marcos Antônio. Corpo estranho: o desamparado que encontra sua política de ser. Revista da FUNDARTE, Montenegro, p.396-415, ano 19, № 37, Janeiro/Março.

Disponível em: http://.seer.fundarte.rs.gov.br/index.php/RevistadaFundarte/index> 30 de março de 2019. 


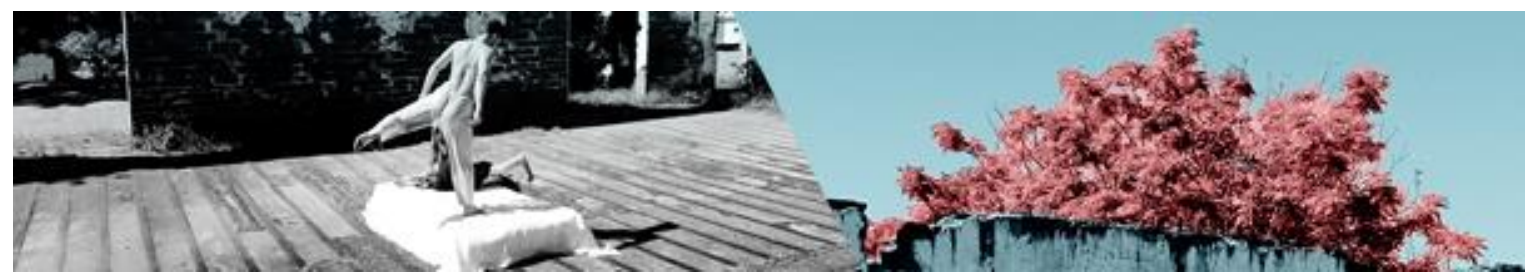

A pedagogia da imperfeição é, portanto, uma pedagogia aqui pensada para o corpo estranho, o corpo que vive na condição de ser menos, que encontra na sua imperfeição a sua liberdade, em busca de tentar poder dizer que é mais. Paulo Freire elucida sobre a questão que haverá dois momentos distintos em pedagogias dessa natureza:

O primeiro, em que os oprimidos vão desvelando o mundo da opressão e vão comprometendo-se, na práxis, com a sua transformação; o segundo, em que, transformada a realidade opressora, esta pedagogia deixa de ser do oprimido e passa a ser a pedagogia dos homens em processo de permanente libertação. (FREIRE, 1987, p. 41).

O corpo estranho abarcado por uma pedagogia da libertação, uma pedagogia que não é nem do oprimido, menos ainda do opressor, possibilita processos de construções múltiplas que, igualmente, contemplará as diferenças em contraposição às divergências. Sendo esta uma prática de construção de conhecimentos, uma pedagogia, realizará transformações profundas na sala de aula, a qual enfrentará a consciência da perfeição como aquela que oprime a deformação de corpos estranhos: as condições impostas que estabelecem quem têm direito de ser mais e/ou quem deve ser menos. Paulo Freire colabora novamente sobre outros dois momentos, agora de consciência:

No primeiro momento, por meio da mudança da percepção do mundo opressor por parte dos oprimidos; no segundo, pela expulsão dos mitos criados e desenvolvidos na estrutura opressora e que se preservam como espectros míticos, na estrutura nova que surge da transformação revolucionária. (FREIRE, 1987, p. 42)

Portanto, não é o método que deve ser alterado de tempos em tempos para reconhecer as diferenças - estranhamentos - dos corpos que circulam nas salas de aula. Mas é preciso reconhecer que os corpos estranhos também são sujeitos que produzem arte, cultura e conhecimentos a partir das suas estranhezas (diferenças). Dessa forma, portanto, o lugar da sala de aula é tanto do oprimido (estudante) quanto o lugar em que se consolida o opressor (professor) que também é oprimido

FARIA, Juliano Ribeiro; BESSA-OLIVEIRA, Marcos Antônio. Corpo estranho: o desamparado que encontra sua política de ser. Revista da FUNDARTE, Montenegro, p.396-415, ano 19, № 37, Janeiro/Março.

Disponível em: http://.seer.fundarte.rs.gov.br/index.php/RevistadaFundarte/index> 30 de março de 2019. 


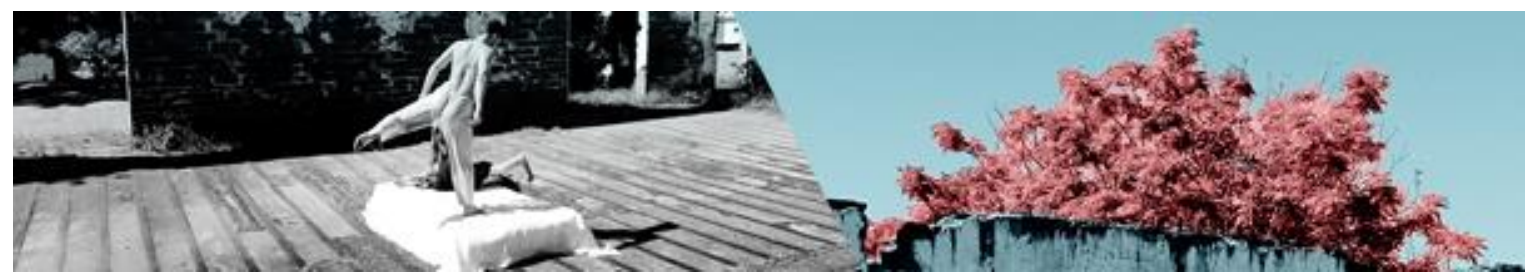

pelo sistema da perfeição (político, econômico, social e/ou cultural) que está ancorado em pensamentos modernos.

Esse diálogo entre pedagogia freiriana e a concepção de corpo estranho aqui defendida me fez elaborar a pedagogia da imperfeição que norteou a realização do meu estágio supervisionado obrigatório deste ano (2018), concluído em escolas públicas de Campo Grande-MS. Nesse estágio tive vivências no ensino fundamental II e no ensino médio, regendo aulas de Dança e Teatro, junto a professores com formação em Artes Visuais. Nesta condição, acabei por me deparar na rotina diária de sala de aula com muitos corpos estranhos que pesquiso na teoria, esses sendo "kahlados" pela estética do belo na prática habitual do atual ensino de Arte.

O corpo estranho se encontra em todo âmbito da escola, seja na organização das cadeiras e mesas, na padronização das camisetas verde e amarelo, nas recomendações dos pais, seja mesmo no conteúdo ensinado pelo educador. 0 educando que tem voz é o que conta sua história belamente. O corpo estranho, portanto, não está restrito ao corpo humano dos estudantes, professores ou dirigentes escolares. Nas escolas onde estagiei foi possível observar:

[um] "corpo político" como conjunto dos elementos materiais e das técnicas que servem de armas, de reforço, de vias de comunicação e de pontos de apoio para as relações de poder e de saber que investem os corpos humanos e os submetem fazendo deles objetos de saber. (FOUCAULT, 1987, p. 31-32).

Em outras palavras, encontrei corpos submissos ao sistema escolar, corpos com seus gestos (estranhos), controlados dentro das escolas que colaboram com a manutenção e a "mecânica de poder" para a construção de corpos dominados (dóceis) como Michael Foucault ainda explica:

[...] ela define como se pode ter domínio sobre o corpo dos outros, não simplesmente para que façam o que se quer, mas para que operem como se quer, com as técnicas, segundo a rapidez e a eficácia que se determina. A disciplina fabrica assim corpos submissos e exercitados, corpos "dóceis". (FOUCAULT, 1987, p. 164).

FARIA, Juliano Ribeiro; BESSA-OLIVEIRA, Marcos Antônio. Corpo estranho: o desamparado que encontra sua política de ser. Revista da FUNDARTE, Montenegro, p.396-415, ano 19, no37, Janeiro/Março.

Disponível em: http://.seer.fundarte.rs.gov.br/index.php/RevistadaFundarte/index> 30 de março de 2019. 


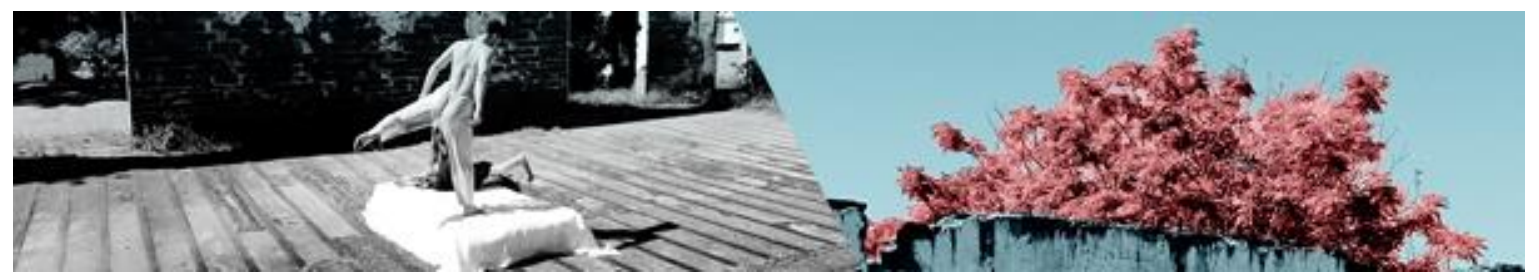

Sendo assim, corpos que carregam o discurso do poder são corpos-poderperfeitos que não dão a oportunidade de outros corpos existirem, e não permitem a existência dos seus próprios corpos já que esta política de poder se faz presente em sua consciência como um pensar-limite sobre o mundo, igualmente porque até mesmo o corpo-poder-política, na ótica freiriana, seria um corpo em estado de opressor/oprimido. Por conseguinte, essa colabora com a manutenção dessa estética de (o)pressão. Guerra e Nolasco (2015) abordam também a influência da mídia sobre o corpo, "uma prática na qual os próprios sujeitos políticos docializam sua aparência e seu gesto para figurar nas diferentes materialidades dos veículos de informação e comunicação" (GUERRA; NOLASCO, 2015, p. 160).

Então, os corpos que descobri na escola são "corpos dóceis", na perspectiva de Michel Foucault (1987), que não oferecem condições de se trabalhar com ele a partir de uma pedagogia bancária, uma prática que não respeita o corpo que pensa e dança e que não contribui para a manutenção do "projeto moderno europeu; [corpos que] não existem e menos ainda têm ideias, razões e emoção" (BESSAOLIVEIRA, 2017, p. 2)

Durante o estágio supervisionado, portanto, para tirar os corpos dóceis dos estudantes da passividade da aula de Artes Visuais, que é a única arte presente nas escolas onde realizei o meu estágio, introduzi aulas de Dança/Teatro como atividade prática. Márcia Strazzacappa (2003) explica que a Lei de Diretrizes e Bases para a Educação (LDB) é nítida ao informar o ensino de arte como componente curricular na educação básica, reconhecendo a relevância das quatro linguagens da arte: Artes Visuais, Dança, Música e Teatro. Porém, foi apenas no ano de 2016 que se abriu concurso público contemplando todas as linguagens da arte na capital de Mato Grosso do Sul.

Deste modo, os estudantes não tinham contato com a dança ou com o teatro em ambas as escolas, havia, por parte de uns, apenas a consciência de que aula de arte "não se resume a atividades de desenhos e pintura e de que ensino de arte é parte integrante da formação do cidadão (STRAZZACAPPA, 2003, p. 79). Para amenizar isso, busquei dialogar com todas as linguagens da arte com aulas dinâmicas e não estáticas. Sendo assim, optei por trabalhar "[...] em um plano de

FARIA, Juliano Ribeiro; BESSA-OLIVEIRA, Marcos Antônio. Corpo estranho: o desamparado que encontra sua política de ser. Revista da FUNDARTE, Montenegro, p.396-415, ano 19, № 37, Janeiro/Março.

Disponível em: http://.seer.fundarte.rs.gov.br/index.php/RevistadaFundarte/index> 30 de março de 2019. 


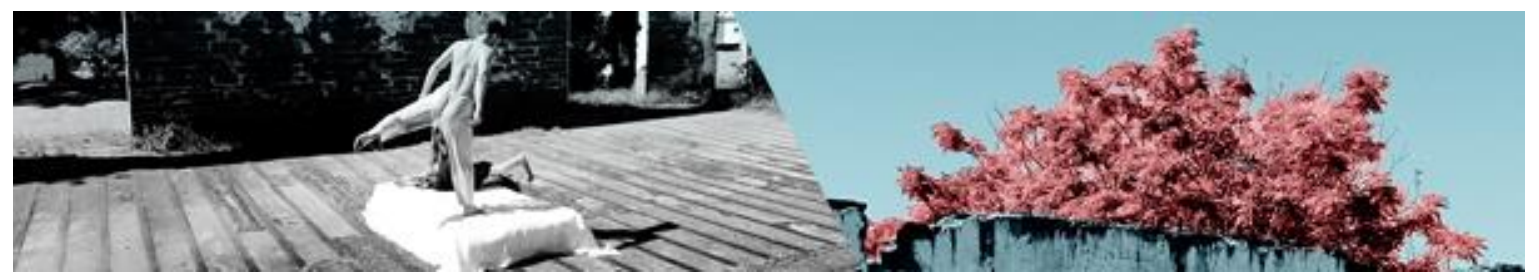

descolonização do conhecer, do sentir, do pensar e do ser" (GOMÉZ; MIGNOLO, 2012, p. 9 [tradução livre minha]) sobre arte nas aulas com os estudantes, a partir de seus corpos sempre vistos como estranhos.

Minha proposta pedagógica da imperfeição se cria/coloca em prática com o fazer descolonial, do corpo, do discurso, da vida, do estudante; diferente ainda da atitude pedagógica proposta por Jussara Miller, que "trabalha com habilidades expressivas e as habilidades técnicas intrinsecamente, sem hierarquias" (MILLER, 2012, p. 90), mas com e como objetos facilitadores. Jussara Miller salienta que para estimular o corpo sensível da criança se utiliza de objetos facilitadores:

\begin{abstract}
Como bolas de diversos tamanhos e texturas, bexigas, saquinhos coloridos, bolas de sabão, língua de sogra, tecidos de diversas medidas e texturas e bambus, entre outros objetos que despertam a criatividade da criança durante a vivência da dança. Quando [utiliza] variados objetos facilitadores - inclusive um modelo representativo do esqueleto humano -, [faz] apenas para mostrar as possibilidades de movimentos articulares de estrutura óssea e para ajudá-las a reconhecer as inúmeras vias para acessar o corpo que dança. (MILLER, 2012, p. 88).
\end{abstract}

No caso da minha proposta pedagógica, entra em cena a estranheza do corpo do próprio estudante como modos de alcançar o fazer (seu próprio) em dança. A autora apresenta princípios para criar um corpo que dança, seja pelo trabalho da "técnica sem perder a sensibilidades" (MILLER, 2012, p. 90) ou com objetos facilitadores. Sua prática emerge da pesquisa e da aplicação da técnica Klauss Vianna, criando um caminho pedagógico para o corpo seguir e alcançar o movimento; não saindo, da nossa perspectiva, da ainda docilidade dos corpos dóceis de Michel Foucault (1987). Dessa forma, minha proposta pedagógica parte de trajetórias que são inventadas, nas quais qualquer corpo pode ter voz e vez para dizer o que pensam e dançam.

A proposta da trajetória inventada se inicia com o corpo do estudante, saindo do seu corpo domesticado pelos saberes disciplinares e encontrando o seu corpo natural indócil na consciência da perfeição de corpo e movimento. Construindo o conteúdo com seu corpo na desobediência, o estudante é levado pelo educador a reconhecer o seu/um corpo estranho que transporta "a experiência constitutiva do

FARIA, Juliano Ribeiro; BESSA-OLIVEIRA, Marcos Antônio. Corpo estranho: o desamparado que encontra sua política de ser. Revista da FUNDARTE, Montenegro, p.396-415, ano 19, ํo 37, Janeiro/Março.

Disponível em: http://.seer.fundarte.rs.gov.br/index.php/RevistadaFundarte/index> 30 de março de 2019. 


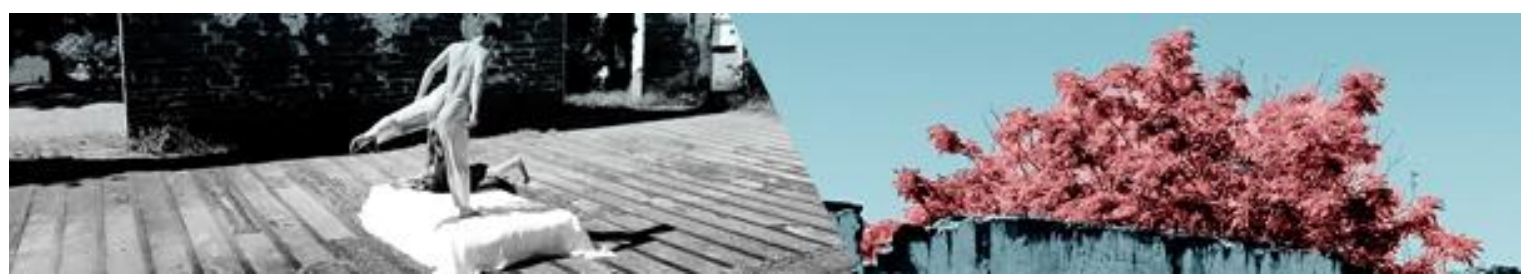

[seu] ser" (MIGNOLO, 2017, p. 23) em uma pedagogia disciplinar; aquela que compreende que os estudantes devem tratar seus corpos doentes com as aplicações de técnicas e "facilitadores" que o fez "humanitas", hoje apagados nas diferenças de si e do outro e daqueles que são colocados como inferior/oprimidos nas fronteiras (im)postas, a exemplo das metodologias usadas para gerar dança a todo custo. No percurso inventado pelos estudantes não existe fronteiras para produzir dança, teatro, musicais ou qualquer outro fazer artístico. O corpo estranho é dança o tempo todo!

Nesse sentido, durante a aula surgiam "temas geradores" dos estudantes (FREIRE, 1987, p. 100); problemas a serem debatidos e entendidos sobre suas realidades. Surgiu, então, o tema de dois meninos, criando e dançando dentro da sala de aula. "Num país onde a herança machista ainda está presente, raramente se veem meninos em aulas de balé. [...] Há papéis bem definidos para homens e mulheres em nossa sociedade" (STRAZZACAPPA, 2006, p. 45-46). No 6음 ano estudantes se valeram de imagens da pré-história para compor dança, rompendo pré-conceitos de que dança é coisa de menina, de que dança é balé e fru-fru. Por livre e espontânea vontade, esses meninos criaram coreografias a partir de trajetórias corporais suas. A seguir apresento algumas ilustrações dos meninos apresentando seus resultados e os outros estudantes assistindo-os de maneira bastante confortável como o corpo (estranho) de cada um que se sentisse mais à vontade.

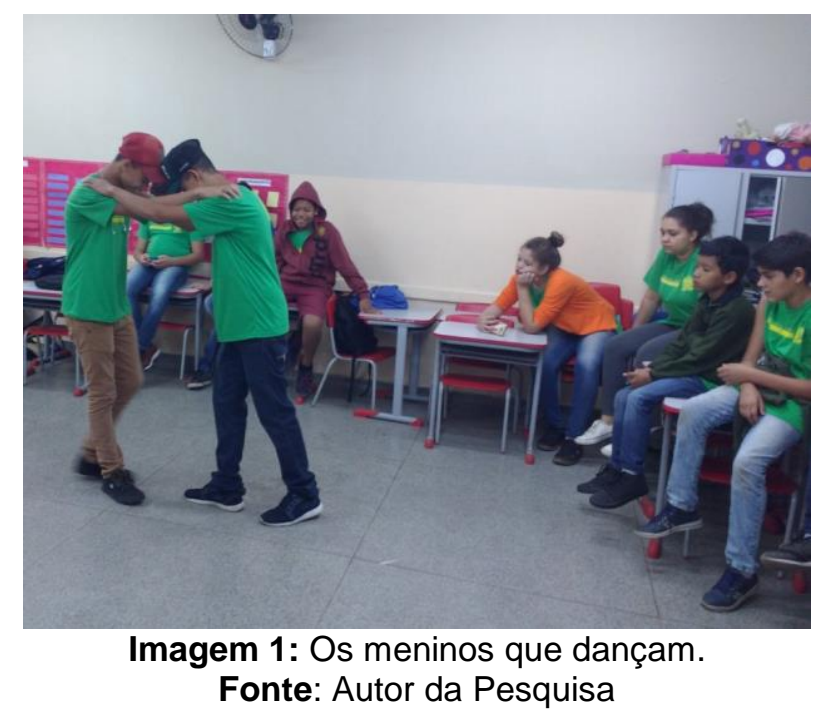

FARIA, Juliano Ribeiro; BESSA-OLIVEIRA, Marcos Antônio. Corpo estranho: o desamparado que encontra sua política de ser. Revista da FUNDARTE, Montenegro, p.396-415, ano 19, no 37, Janeiro/Março.

Disponível em: http://.seer.fundarte.rs.gov.br/index.php/RevistadaFundarte/index> 30 de março de 2019. 

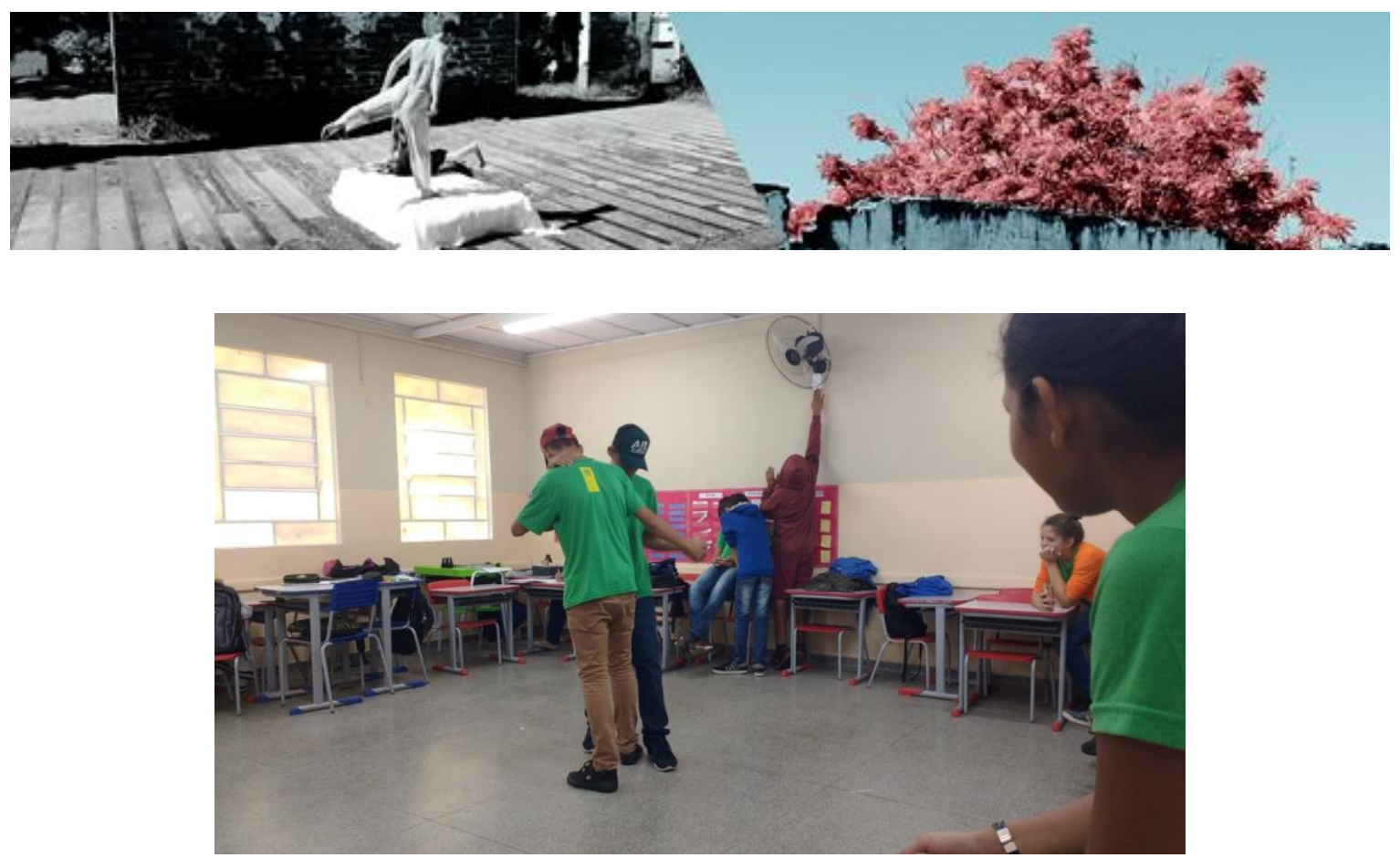

Imagem 2: O não-lugar da herança machista na sala de aula, dito por eles pelo seus corpos em movimentos.

Fonte: Autor da Pesquisa

O resultado de coreografia dos estudantes se deu por não haver cobrança da perfeição no processo que é também imperfeito, acolhendo seus corpos, como são produtores de conhecimento, sem correções, "É preciso trabalhar de acordo com os participantes. Basta ver como eles são para saber do que precisam" (BERTHERAT, 2010, p. 30). E aqueles corpos-estudantes precisavam encontrar as suas casas onde não moram. Buscar opções:

[...] não de uma estética ou de uma história moderna, mas de estéticas e histórias particulares, localizadas que, no entanto, apontam para horizontes comuns em uma diversidade não homogênea de saberes, conhecimentos e práticas. (GOMÉZ; MIGNOLO, 2012, p. 13 [Tradução livre minha]).

O mesmo ocorreu com os estudantes do ensino médio que compuseram uma coreografia imperfeita a partir da letra da música do Rapper Emicida, com participação de Vanessa da Mata: um fragmento da letra da música que diz "Passarinhos soltos a voar, dispostos a achar um ninho, nem que seja no peito um do outro" serviu de pre"texto" para a construção. Os estudantes-corpos apresentaram os trabalhos desenvolvidos por eles, e, ao final, se expressaram sobre

\footnotetext{
${ }^{4}$ Emicida. Participação especial de Vanessa da Mata. Produção: Emicida \& Xuxa Levy. Album Sobre Crianças, Quadris, Pesadelos e Lições de Casa. "Passarinhos". Disponível em: https://www.vagalume.com.br/emicida/passarinhos-part-vanessa-da-mata.html- - acessado em 17/06/2017.
}

FARIA, Juliano Ribeiro; BESSA-OLIVEIRA, Marcos Antônio. Corpo estranho: o desamparado que encontra sua política de ser. Revista da FUNDARTE, Montenegro, p.396-415, ano 19, № 37, Janeiro/Março.

Disponível em: http://.seer.fundarte.rs.gov.br/index.php/RevistadaFundarte/index> 30 de março de 2019. 


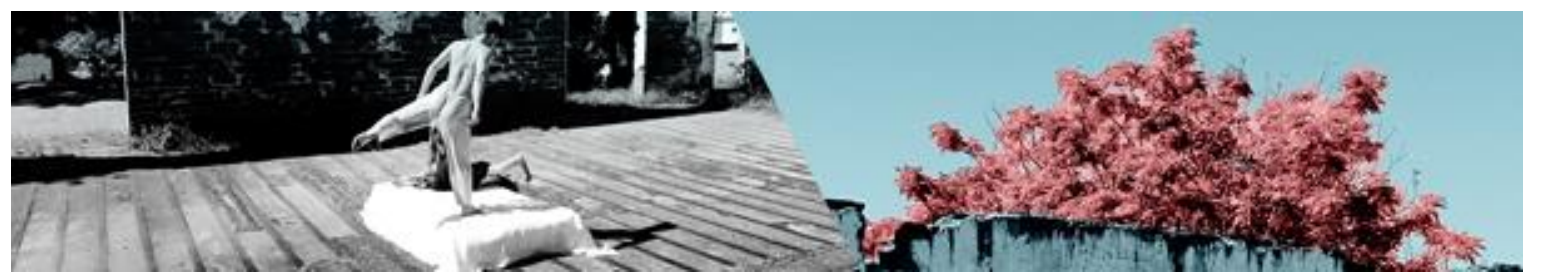

o processo que construíram na imperfeição. Falaram que seu trabalho tratava da importância do abraço, da amizade entre os pares, abrindo seus corpos, antes dóceis, que são kahlados na pedagogia da perfeição porque não produzem arte, cultura, conhecimentos, puderam se comunicar e receber o abraço um do outro. A expressão da fala também faz parte da pedagogia da imperfeição, pois é o momento em que o corpo estranho também fala a partir de si. Constrói suas narrativas a partir das suas biogeografias: com o seu corpo (sujeito), do seu espaço (geo), tendo como escopo às suas histórias locais (narrativas) não contempladas pelas histórias e geografias universais (da perfeição).

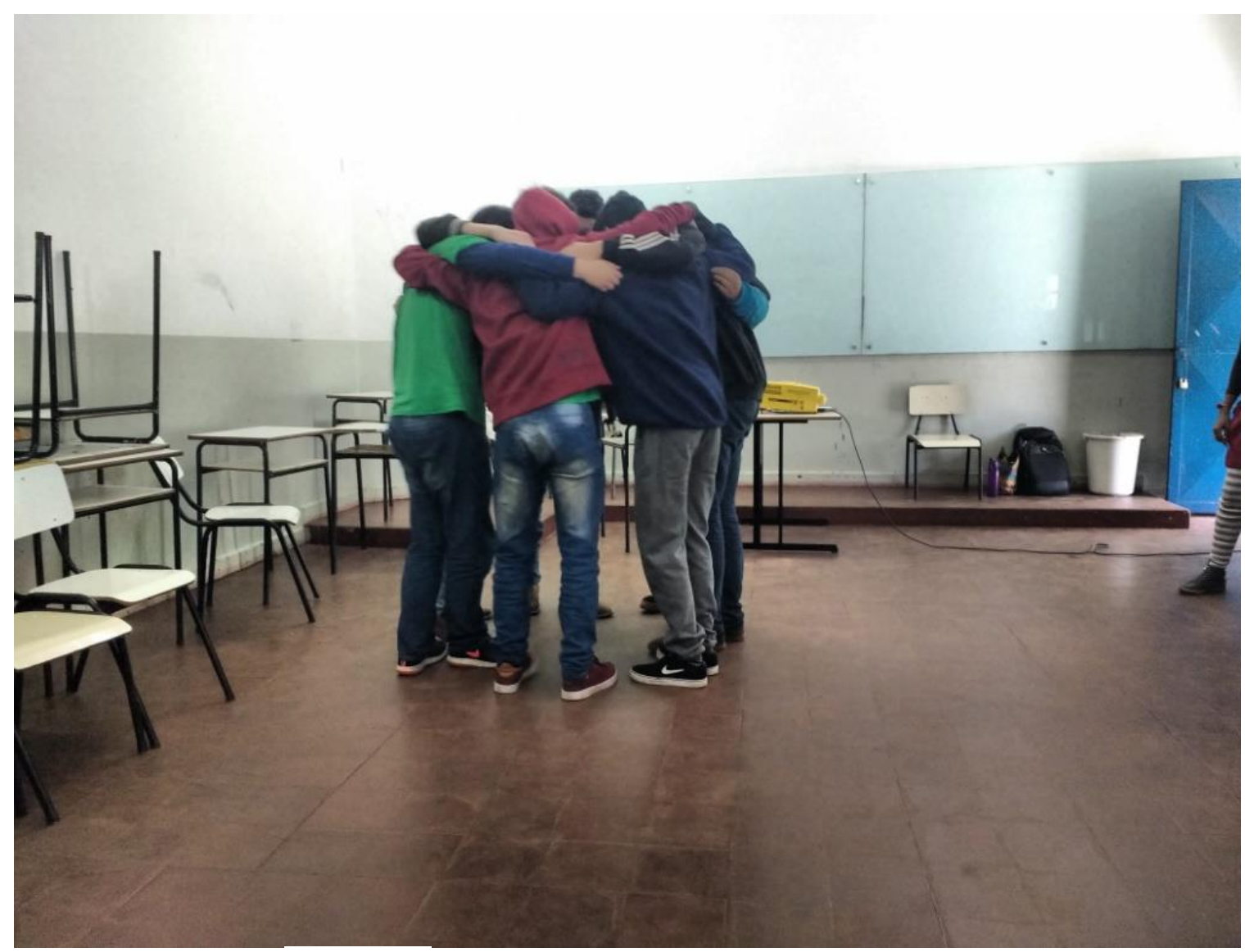

Imagem 3: Um abraço verdadeiro construído por eles.

Fonte: Autor da pesquisa

FARIA, Juliano Ribeiro; BESSA-OLIVEIRA, Marcos Antônio. Corpo estranho: o desamparado que encontra sua política de ser. Revista da FUNDARTE, Montenegro, p.396-415, ano 19, ํㅡ 37, Janeiro/Março.

Disponível em: http://.seer.fundarte.rs.gov.br/index.php/RevistadaFundarte/index> 30 de março de 2019. 

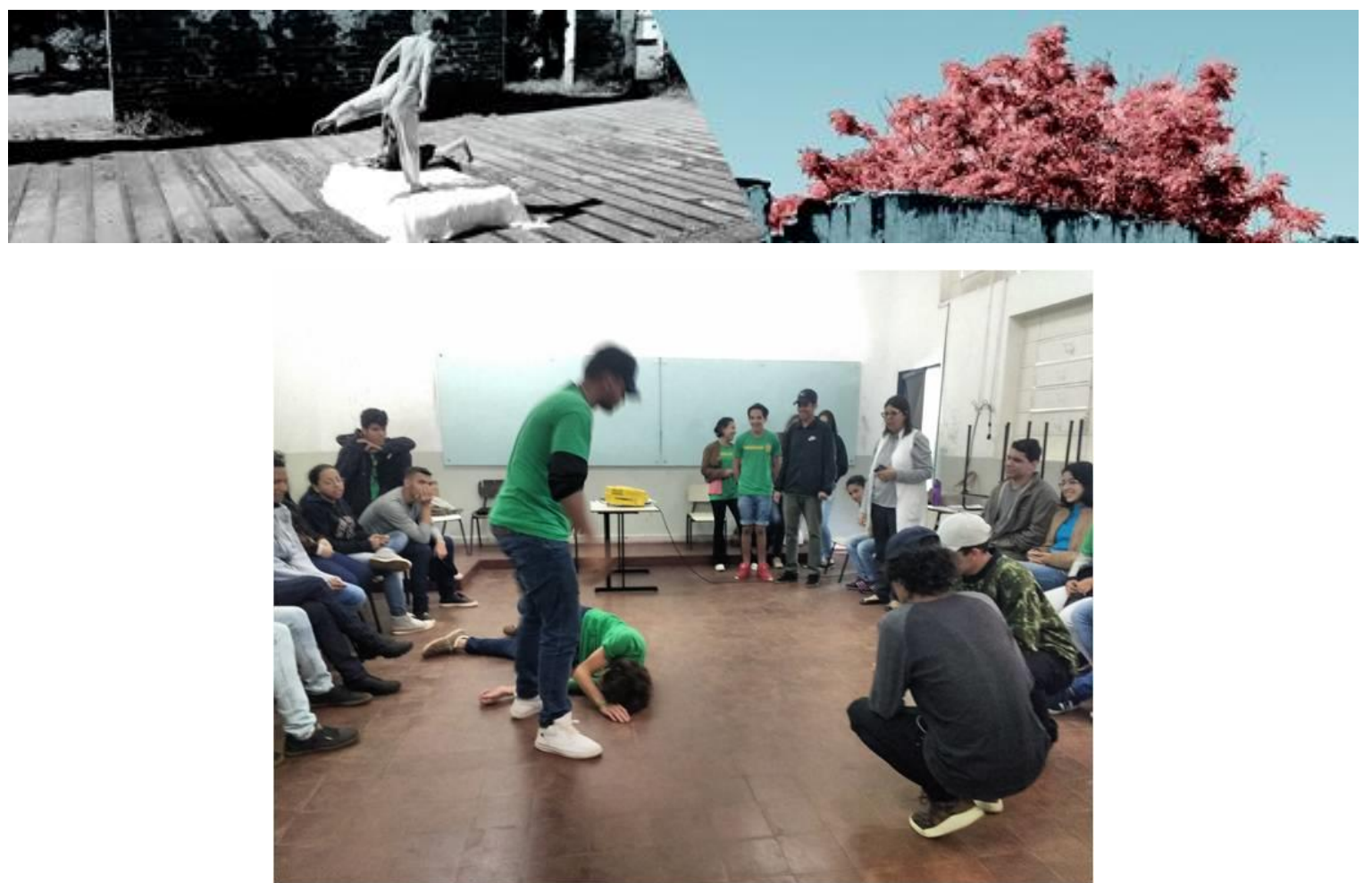

Imagem 4 : O "ser mais" diferente, fruto da pedagogia da imperfeição.

Fonte: Autor da pesquisa.

\section{Considerações finais - qual corpo não fala?}

Considero o conceito criado de corpo estranho, um corpo que transposta sua memória, história e biogeografia particulares, fazendo a diferença no mundo em que vive; reconhecer-se como um corpo latino, que não nega sua nacionalidade (FARIA; BESSA-OLIVEIRA, 2017, p. 1), um corpo com ato político para dar visualidade a si; como produtor de saberes através de suas imperfeições. Vejo que se tornou uma "prática social esclarecida, mais transparente, mais igualitári, mais democrático" (HISSA, 2011, p. 20), a prática naquelas aulas de Arte, pelo motivo de contemplar a todos os corpos dentro e fora das salas de aula. Todos os corpos necessitam se valer de seus corpos imperfeitos para sair da docilidade do corpo perfeito, do corpo submisso e exercitado (como corpo mais que perfeito), fabricado pela disciplina (FOUCAULT, 1987) da consciência da perfeição moderna. O corpo estranho é um corpo-política que cria saberes faltantes:

Assim, o corpo-política e o lado negro e a metade faltante da biopolítica que é apenas a metade da história: o corpo-política descreve as tecnologias descoloniais aplicadas aos corpos que se dão conta que foram considerados menos humanos, no momento em que tomam consciência de que 0 ato mesmo de ser descritos como menos humanos era uma consideração inumana. Portanto, a falta de humanidade atribuída a todas as populações não europeias é apresentada em atores imperiais, instituições e

FARIA, Juliano Ribeiro; BESSA-OLIVEIRA, Marcos Antônio. Corpo estranho: o desamparado que encontra sua política de ser. Revista da FUNDARTE, Montenegro, p.396-415, ano 19, № 37, Janeiro/Março.

Disponível em: http://.seer.fundarte.rs.gov.br/index.php/RevistadaFundarte/index> 30 de março de 2019. 


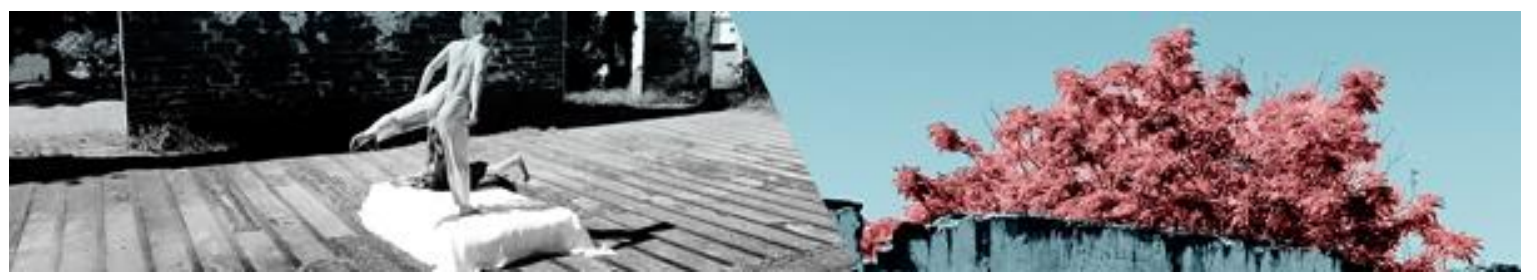

conhecimentos que tiveram a arrogância de decidir que certas pessoas que não lhes agradavam [ou que não gostavam deles], eram menos humanas. O corpo-política é um componente fundamental do pensamento descolonial, é um fazer descolonial e a opção descolonial para revelar, em primeiro lugar, as táticas da epistemologia imperial para afirmar a si mesma como humanitas do primeiro mundo desenvolvido e, por outro lado, levar o empreender da criação de saberes descoloniais que respondem às necessidades dos anthropos do mundo subdesenvolvido e em vias de desenvolvimento. (MIGNOLO, 2009, p. 33 [Tradução livre minha]).

Quer dizer, esse corpo estranho (política) é bem diferente do corpo político de Foucault (1987) e dos corpos parecidos com ele que fazem a manutenção do poder saber, postos com a "herida colinial" (GÓMEZ; MIGNOLO, 2012, p. 16) aberta pela noção e manutenção da estética do belo até no trabalho docente dentro das salas de aula na disciplina de Arte. Trabalhar para naturalizar os corpos para ser ele mesmo é emergência contemporânea, mas esse trabalho deve se dar como e com um pensamento outro, por exemplo: a opção decolonial, que é a de naturalizar em vez de modernizar corpos (MIGNOLO, 2009, p. 26).

Finalmente, então, por meio da pedagogia da imperfeição criada com/pelos corpos estranhos, sem julgamentos de ser mais ou ser menos, pois todos são seres humanos da diferença, apenas possuímos biogeografias diferentes, é que podemos humanizar e ensinar/aprendendo, a partir da escuta e da observação de si e do outro, enxergando um (vários) mundo real. Mas isto só é possível quando se tem um educador que sabe o quanto dói viver sob a classificação e sofre ainda porque tem 0 conhecimento de um outro corpo habitado por ele no seu corpo estranho. O "educador" opressor, ainda que oprimido (FREIRE), jamais poderá (re)conhecer(si) corpos estranhos! Igualmente esse sujeito sofre por reconhecer a necessidade de empoderamento das "biogeografias, bio - corpo estranho, geo - espaço da opressão, da inexistência, grafias - narrativas de rejeição e superação (FARIA; BESSA-OLIVEIRA, 2018, p. 1) da diferença; que na maioria das vezes não têm direitos para fazer a diferença: seja na sua prática docente pedagógica, seja na sua prática discente como estudantes, promovendo vidas.

FARIA, Juliano Ribeiro; BESSA-OLIVEIRA, Marcos Antônio. Corpo estranho: o desamparado que encontra sua política de ser. Revista da FUNDARTE, Montenegro, p.396-415, ano 19, № 37, Janeiro/Março.

Disponível em: http://.seer.fundarte.rs.gov.br/index.php/RevistadaFundarte/index> 30 de março de 2019. 


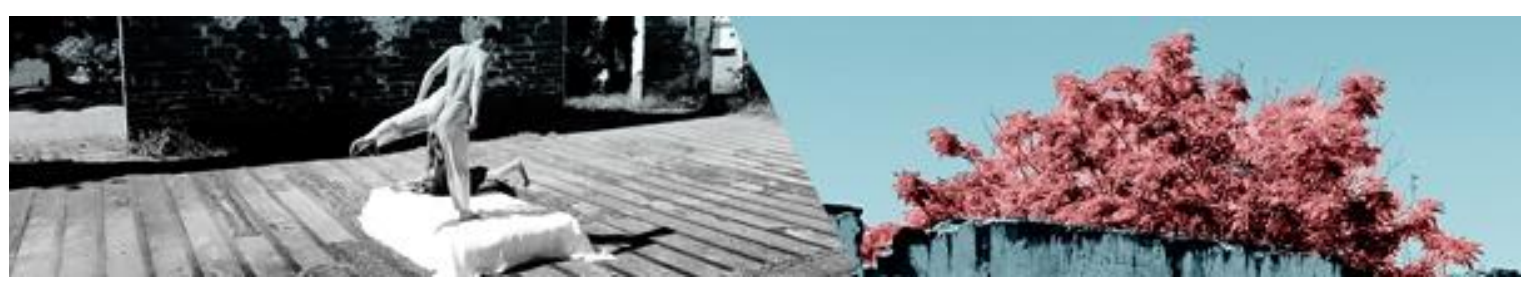

\section{Referências:}

BERTHERAT, Thérèse. O corpo tem suas razões: antiginástica e consciência de si. Com colaboração de Carol Bernstein; tradução Estrela dos Santos Abreu. 21a. Ed. São Paulo: Editora WMF Martins Fontes, 2010.

BESSA-OLIVEIRA, Marcos Antônio. "AS FRONTEIRAS QUE ES MAS PRODUÇÕES CULTURAIS DA EXTERIORIDADE”. Comunicação Oral apresentada durante o 130 CICLO DE INVESTIGAÇÕES PPGAV: . Centro de Artes (CEART) da Universidade do Estado de Santa Catarina (UDESC) realizado Florianópolis, Santa Catarina nos dias 3, 4 e 5 de setembro de 2018, p. 1-10

BESSA-OLIVEIRA, Marcos Antônio. "(DE)CORPOSIÇÃO - CARVÃO E TINTA EM CORPONEG(R)ADO”. In: BESSA-OLIVEIRA, MARCOS ANTÔNIO. (Org.). Anais da Jornada de Artes da UEMS 2018: para que serve o ensino das artes na escola?. Anais...Campo Grande(MS) UEMS - Universidade Estadual de Mato Grosso do Sul, UUCG - Unidade Universitária Campo Grande, 2018a. Disponível em: $<$ https://www.even3.com.br/Anais/jart/108767-(DE)CORPOSICAO--CARVAO-E-

TINTA-EM-CORPONEG(R)ADO>. Acesso em: 04/11/2018 11:20

BESSA-OLIVEIRA, Marcos Antônio."Fronteira, biografia - biogeografias - como episteme descolonial para (trans)bordar corpos em artes da cena". In: Revista Conceição/Concept. Campinas, SP, v. 7, n. 1, jan./jun. 2018b, p. 142-157. Disponível em:

https://periodicos.sbu.unicamp.br/ojs/index.php/conce/article/view/8648471/18307. Acesso em 06/11/2018.

BESSA-OLIVEIRA, Marcos Antônio. " "O corpo que habito: esse não é o corpo da sala de aula, dos museus, nem o corpo da academia!". In: Acervo do autor. Campo Grande, MS, 2017, p. 1-15. (Texto no prelo).

BESSA-OLIVEIRA, Marcos Antônio. "(Trans)bordar Fronteiras: Estética Bugresca para Descolonizar Corpos Biogeográficos ". In. Memória ABRACE XVI - Anais do IX Congresso da Associação Brasileira de Pesquisa e Pós-Graduação em Artes Cênicas. Anais... Uberlândia (MG) UFU, 2017. Disponível em www.even3.com.br/anais/IXCongressoABRACE - acessado em: 08 de fevereiro de 2017 , p. 4,493-4.518.

BESSA-OLIVEIRA, Marcos Antônio. "Ensino de Artes X Estudos Culturais: para além dos muros da escola. São Carlos, SP: Pedro \& João Editores, 2010.

DERRIDA, Jacques. Mal de arquivo: uma impressão freudiana. Trad. Claudia de Moraes Rego. Rio de Janeiro: Relume Dumará, 2001.

FARIA, Juliano Ribeiro; BESSA-OLIVEIRA, Marcos Antônio. Corpo estranho: o desamparado que encontra sua política de ser. Revista da FUNDARTE, Montenegro, p.396-415, ano 19, no 37, Janeiro/Março.

Disponível em: http://.seer.fundarte.rs.gov.br/index.php/RevistadaFundarte/index> 30 de março de 2019. 


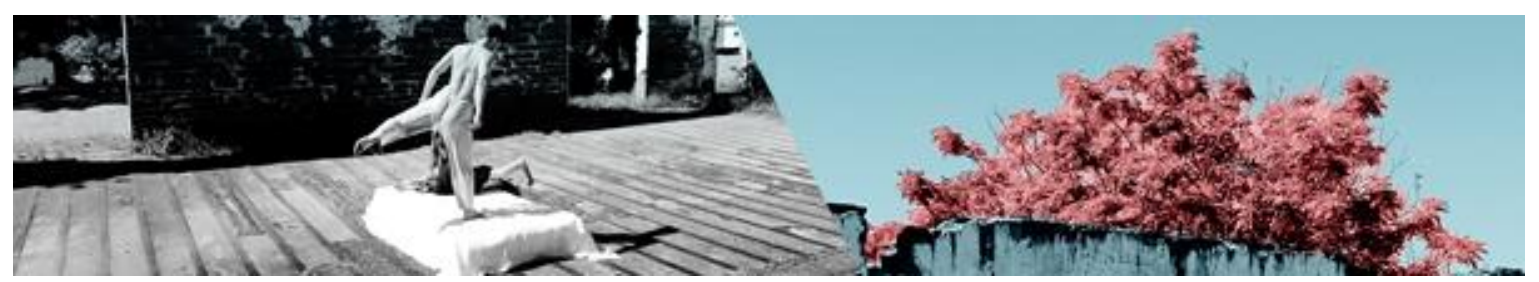

DERRIDA, Jacques. Gramatologia. Trad. Miriam Schnaiderman e Renato J. Ribeiro. São Paulo: Perspectiva, 1973.

FARIA, Juliano Ribeiro; BESSA-OLIVEIRA, Marcos Antônio. "CORPO ESTRANHO DA PERNA DE PAU: (UM SER MAIS) QUE HUMANIZA OS LUGARES QUE (DES)OCUPA ESCOLA E SOCIEDADE". In: BESSA-OLIVEIRA, MARCOS ANTONIO.. (Org.). Anais da Jornada de Artes da UEMS 2018: para que serve o ensino das artes na escola?. Anais... Campo Grande(MS) UEMS - Universidade Estadual de Mato Grosso do Sul, UUCG - Unidade Universitária Campo Grande, 2018. Disponível em: <https://www.even3.com.br/Anais/jart/109653-CORPOESTRANHO-DA-PERNA-DE-PAU--(UM-SER-MAIS)-QUE-HUMANIZA-OSLUGARES-QUE-(DES)OCUPA-ESCOLA-E-SOCIEDADE>. Acesso em: 04/11/2018 18:06.

FARIA, Juliano Ribeiro; BESSA-OLIVEIRA, Marcos Antônio. "CORPOS ESTRANHOS: um "kahlo" para além dos muros da escola". In: PAES, Ademilson Batista; FIGUEIRA, Kátia Cristina Nascimento. (Orgs.). Anais Eletrônicos do IV EHECO, Campo Grande, MS, 2017, ISSN 22374310. Disponível em: http://eheco.com.br/ARQUIVOS/ANAIS/Juliano\%20Ribeiro\%20de\%20Faria.pdf _ acessando em: 04/11/2018.

FARIA, Juliano Ribeiro; BESSA-OLIVEIRA, Marcos Antônio. "O CORPO "SOFRIDO KAHLO" NA ESCOLA: CORPOS ESTRANHOS QUE RE-EXISTEM!. In: Acervo do autor. Campo Grande, MS. 2017a, p. 1-13. (Texto no prelo)

FREIRE, Paulo. Pedagogia do oprimido. Rio de Janeiro: Editora Paz e Terra, 1987. FOUCAULT, Michel. Vigiar e Punir: nascimento da prisão. Trad. Lígia M. Ponde Vassalo. Petrópolis: Vozes, 1987.

GÓMEZ, Pedro Pablo. MIGNOLO, Walter. "Esteticas decoloniales. sentir. pensar Hacer en Abya yala y la gran comarca". In: GÓMEZ, Pedro Pablo. Estéticas decoloniales. [recurso electrónico]. Bogotá: Universidad Distrital Francisco José de Caldas, 2012, $\quad$ p. $6-23 . \quad$ Disponível em: https://adelajusic.files.wordpress.com/2012/10/decolonial-aesthetics.pdf - acessado em: 22/10/2018.

GREINER, Christine. "Em busca de uma metodologia para analisar a alteridade na arte". In: Conceição I Concept. Campinas, SP, v. 6, n. 2, p. 10-21, jul./dez. 2017. Disponível https://periodicos.sbu.unicamp.br/ojs/index.php/conce/issue/view/1417/showToc acesso em: 06/11/2018.

GUERRA, Vânia Maria Lescano; NOLASCO, Edgar Cézar. (Orgs.). Michel Foucault: entre o passado e o presente, 30 anos de (des)locamentos. Campinas, SP: Pontes Editores, 2015.

FARIA, Juliano Ribeiro; BESSA-OLIVEIRA, Marcos Antônio. Corpo estranho: o desamparado que encontra sua política de ser. Revista da FUNDARTE, Montenegro, p.396-415, ano 19, no37, Janeiro/Março.

Disponível em: http://.seer.fundarte.rs.gov.br/index.php/RevistadaFundarte/index> 30 de março de 2019. 


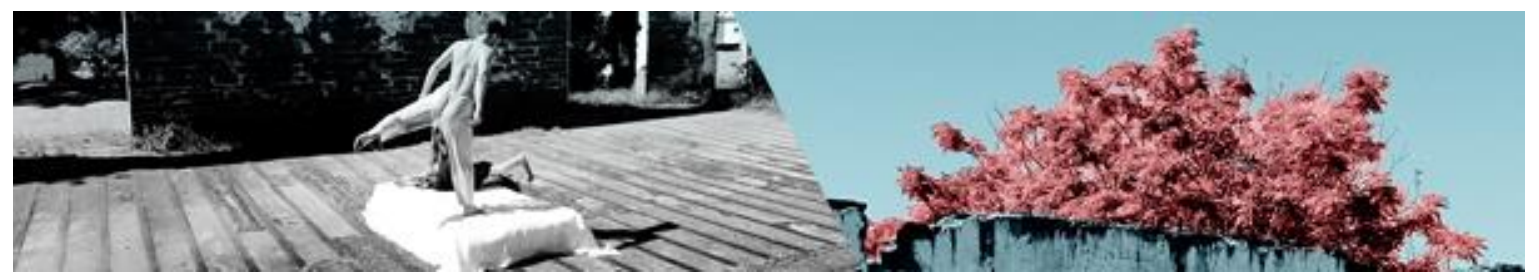

HISSA, Cássio E. Viana. (Org.). Conversações: de artes e de ciências. Belo Horizonte: Editora UFMG, 2011. (Humanitas).

MIGNOLO, Walter. "Desafios Decoloniais Hoje". In: Epistemologias do Sul. Foz do Iguaçu/PR, 1 (1), pp. 12-32, 2017. Disponível em: https://revistas.unila.edu.br/epistemologiasdosul/article/download/772/645 acessado em $22 / 11 / 2017$.

MIGNOLO, Walter D.. "Desobediência epistêmica: a opção descolonial e o significado de identidade em política". In: Cadernos de Letras da UFF: Dossiê: Literatura, língua e identidade, n.34, 2008, p. 287-324. Disponível em: www.uff.br/ cadernosdeletrasuff/34/traducao.pdf - acessado em: 08/07/2018.

MIGNOLO, Walter D.. "Desobediencia epistémica II. Pensamiento independiente y libertad De-colonial". In: Otros logos - Revista de Estudios Críticos. Año I. Nro. 1. 2009, Centro de Estudios y Actualización en Pensamiento Político, Decolonialidad e Interculturalidad. Universidad Nacional del Comahue - Facultad de Humanidades. Neuquén - Argentina, p. 8-42. Disponível em: http://www.ceapedi.com.ar/otroslogos/revistas/0001/mignolo.pdf - acessado em: 05 de maio de 2016.

MIILLER, Jussara. Qual é o corpo que dança?: dança e educação somática para adultos e crianças. São Paulo: Summus, 2012.

STRAZZACAPPA, Márcia e MORANDI, Carla. Entre a Arte e a Docência: formação do artista da dança. Campinas SP: Papirus, 2006.

STRAZZACAPPA, Márcia. Dança na educação. Discutindo questões básicas e polêmicas. In: Pensar a Prática no. 6., Jul./Jun., p. 73-85. 2002-2003. Disponível em: https://www.revistas.ufg.br/fef/article/view/55/54. Acesso em: 08/03/2018.

FARIA, Juliano Ribeiro; BESSA-OLIVEIRA, Marcos Antônio. Corpo estranho: o desamparado que encontra sua política de ser. Revista da FUNDARTE, Montenegro, p.396-415, ano 19, № 37, Janeiro/Março.

Disponível em: http://.seer.fundarte.rs.gov.br/index.php/RevistadaFundarte/index> 30 de março de 2019. 